\title{
Vietnam's dioxin problem
}

\section{Much of Vietnam was sprayed with herbicides during the war. Alastair Hay reports on local research to assess the damage caused.}

M ANY times has the United States been accused of using Vietnam as a testing ground for some of the more sophisticated techniques of modern warfare. Indeed, that accusation featured prominently in much of the Vietnamese propaganda material produced during the last ten years of the war. The Vietnamese, however, were not the only accusers: United States scientists were among some of the more vocal critics of their country's military policies. Many of them made it known that they deplored such practices as the use of chemical defoliants; the implementation of weather-modification techniques; the development of plastic-pellet bombs, the intention of which was to produce shrapnel undetectable by $\mathrm{x}$-rays; and the training of dolphins and porpoises to place limpet mines. All these they considered to be perversions of scientific endeavour.

Their opposition, however, had little effect upon the United States' military

VIETNAM occupies a long narrow strip of Indo-China. The South China Sea is the eastern boundary and a series of mountain ranges in the west act as a natural frontier with Laos and Kampuchia.

Most of Vietnam's population estimated at 50 million reside in the coastal plain and the delta regions of the Red River and the Mekong. Hanoi, the capital city, houses about 1.3 million people; Ho Chi Minh City has about 3.5 million. Five sixths of the country's population is, ethnically speaking, true Vietnamese; some 39 minority groups, of which the "Montagnards" and Chinese settlers are the largest, account for the other sixth.

Vietnam has had various occupation forces in the past two millennia. China kept her as a province from $111 \mathrm{BC}$ until ousted by a national Vietnamese army in $905 \mathrm{AD}$. Subsequent attempts by successive Chinese emperors to recolonise Vietnam met with no success and the country enjoyed independence until occupied by French troops in 1858. French suzerainty in Vietnam ended in 1954, only to be partially replaced by an American presence in the south of the country. The United States, however, had a much shorter stay than France. American involvement in Vietnam finally ended with the fall of Saigon (now Ho Chi Minh City) to Communist troops in April 1975.

The war in Vietnam has exacted a heavy toll on the country with most of her resources being devoted to the war effort. The result of this is that the per capita income is exceedingly low and United Nation's sources confirm that Vietnam activity. In many instances, information was made public only long after the event and the United States always denied emphatically that Vietnam was used as a test site for the development of military technology. But it was the first country in which defoliants were used on a large scale purely to achieve a military objective.

Originally research into 2,4-dichloroplenoxyacetic acid (2,4-D) and 2,4,5trichloroplenoxyacetic acid (2,4,5-T) and related herbicides had been carried out during the Second World War. The British later tested their effectiveness in small-scale operations during the Malayan 'emergency' of the 1950s. But it was the success of herbicide evaluation trials in South Vietnam, Thailand, Hawaii and Puerto Rico which led to the chemicals being employed on a vast scale in Vietnam. According to a US National Academy of Sciences report of 1974 on 'Herbicides in South Vietnam', more than $10 \%$ of the inland forests, $36 \%$ of the

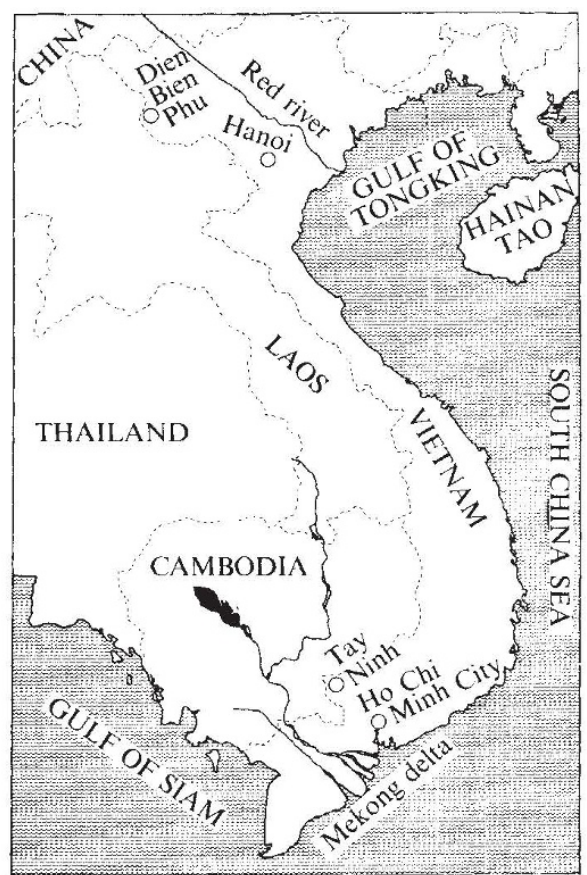

qualifies for urgent development aid. The distribution of aid provided by foreign donors is therefore the subject of some scrutiny. Vietnam does, however, ration food to ensure fair distribution. She has a free education programme and places great emphasis on preventive medicine. These are strategies which are generally welcomed by the international development agencies. mangrove forests, $3 \%$ of cultivated and $5 \%$ of 'other' land was sprayed "one or more" times.

NAS estimates of the total volume of herbicide dropped on Vietnam are 17.5 million gallons, of which 11.25 million gallons was in the form of 'Agent Orange' (a 50:50 mixture of the n-butyl esters of 2,4-D and 2,4,5-T). Criticism of the use of these herbicides on ecological grounds had little impact on the actual spraying missions. With powerful advocates in the American Chemical Society defending the use of herbicides as a more 'humane' form of warfare, it required more than a concern for ecology to bring the spraying to an end.

When the US Department of Health, Education and Welfare published a report in 1969 announcing that 2,4,5-T was teratogenic in rats and mice, the herbicide programme diminished. The report was confirmed by a later independent study which established that commercial preparations of $2,4,5-\mathrm{T}$ contained a highly toxic contaminant, 2,3,7,8-tetrachlorodibenzo-p-dioxin (dioxin), a teratogen at the $\mu \mathrm{g}$ per $\mathrm{kg}$ level in experimental animals.

Sample stocks of Agent Orange retrieved from Vietnam for analysis by the manufacturer, the Dow Chemical Co., revealed dioxin to be present in concentrations of $0.05-47 \mathrm{ppm}$. On the basis of these figures, it has been estimated that at least $100 \mathrm{~kg}$ of dioxin was deposited on Vietnam.

\section{Not just a matter for science}

The damage caused by herbicides is a subject of some concern to the Vietnamese authorities, and is an area of investigation for some of the country's scientists and clinicians. If the dioxin problem in Vietnam was simply one of scientific investigation, more published information would be available by now for scrutiny. But some authorities in Vietnam fear that information on the herbicide damage will be used by the military in the United States to refine its chemical warfare techniques.

Dr Tran Tri, one who voices that anxiety, is in charge of scientific relations with western countries. He says that the dioxin issue is a "complicated" matter and adds: "Of course, there is a scientific aspect to this problem which the Americans have used; our scientists, however, will not use the results in the same way". Tri wants Vietnamese scientists to do much of the general investigation on dioxin. Because of the sensitivity of the subject, he states categorically that only very few of those foreign scientists who have expressed an interest will be able to participate.

Not all Vietnam's scientists agree with Tri's interpretation. Some feel sure that the United States has more 


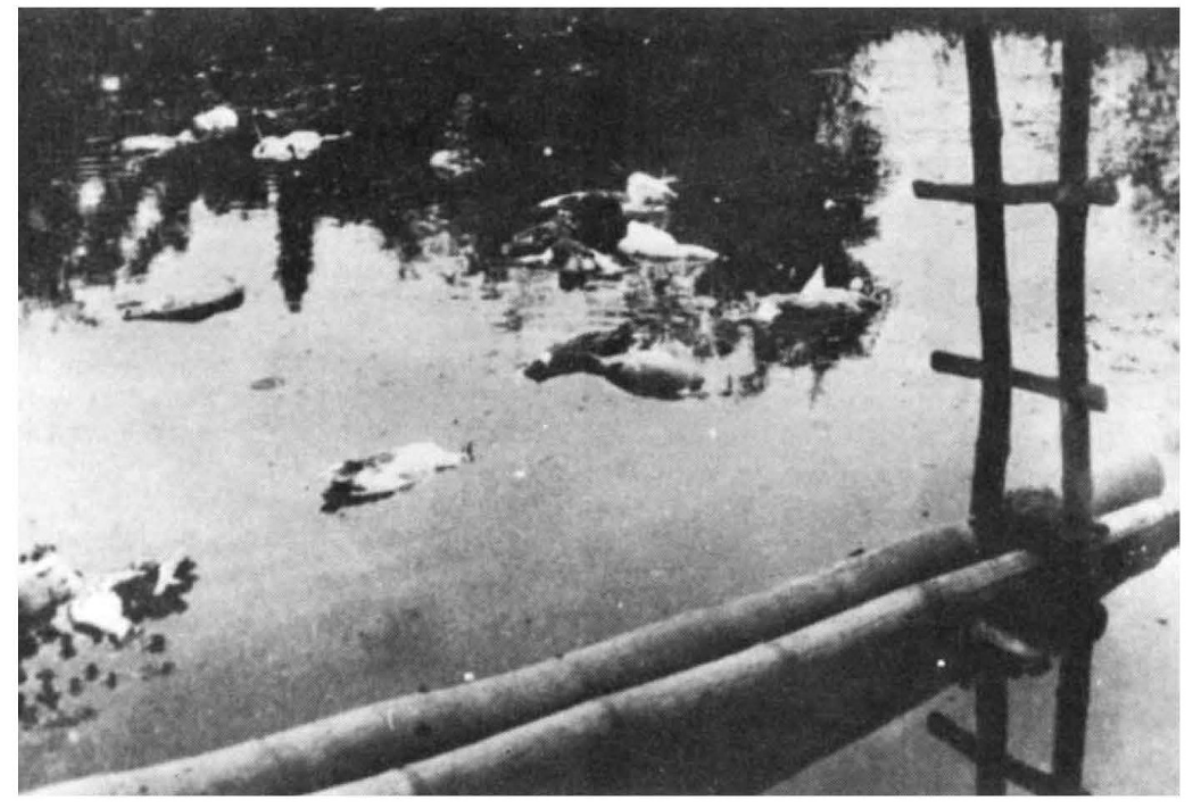

Vietnamese poultry killed by toxic chemicals

than enough information on herbicides. Scientists in the West working on $2,4,5,-T$ and dioxin are of the same opinion. They point to the herbicide trials undertaken in South-East Asia in the 1960 s, and to those run by the US Air Force in Florida from 1962 to 1974. Reports of the Florida experiments-which also contained information on the toxicity and biological degradation rates of dioxin-were declassified in October, 1976, to enable the Italian authorities to make use of them in dioxin decontamination work following the accident at Séveso.

Two of those most involved with the herbicide issue in Vietnam are a cytologist Dr Bach Quôc Tuyen; and Professor Ton That Tung, a surgeon and director of the Viet Duc hospital. Tuyen is in charge of the cytogenetics laboratory at the Bach Mai Hospital in Hanoi. His department was virtually destroyed when the hospital was the target of the 'Christmas bombing' of the city in December 1972.

\section{Reporting chromosomal abnormalities} The cytogenetics department is compiling a register of the incidence of malformation in several districts both in and around Hanoi. It will be the first register to provide an accurate picture in this part of Vietnam, says Tuyen. As a scientist, he is better known for his work on chromosome mapping, and as one of the authors of two papers, published in Vietnam, which claim that the incidence of chromosome damage in pcople exposed to the herbicide 2,4,5-T (and its dioxin contaminant) in the American defoliation programme is higher than expected. But the number of people involved is too small to indicate statistically significant trends. This is "because we did the work during the war", says Tuyen, and he adds: "We had no opportunity to do a controlled epidemiological survey".

Some scientists in the West have levelled another criticism at Tuyen's reports. They say that the Vietnamese have reported as abnormal a level of chromosomal abnormalities - gaps and breaks-considered normal in the West. 'Tuyen estimates that in Vietnam these abnormalities are of the order of $0.4 \%$; for the West and Japan, they are much higher-at $1.0 \%$ or more. To what does Tuyen attribute this higher rate? "Chemicals. Perhaps a higher background level of radiation". And is he satisfied that his laboratory techniques are above reproach? "Yes. Scientists from Holland have verified the accuracy of our work"

\section{Lack of contact with the West}

Like many of the Vietnamese scientists, Tuyen is unable to obtain much of the published literature from the West, due mainly to the effects of war, and current lack of resources. Tuyen would welcome more contact with western scientists. He feels that it is important to conduct further studies to confirm two earlier reports by American scientists on the effects of herbicides on Vietnam.

One of the reports, in the US Congressional Record for 2-9 March 1972, states that there was a marked increase in the incidence of stillbirths in one province, Tay Ninh. The second report-by Arthur Westing to the Swedish Academy of Scientists meeting in February 1977--speaks of an increase in the rate of spina bifida and cleft palate in a Saigon (Ho Chi Minh City) children's hospital from 1966-68, the years of the heaviest spraying programmes. Tuyen is convinced that the defoliation programme has resulted in an increase in the rate of birth abnormalities and chromosomal aberrations, but, until further information is available, he acknowledges that this conclusion is still very uncertain.

The same is true of Professor Tung's suggestion that dioxin may be responsछ ible for an increase in primary carcinoma of the liver in Vietnam. Although Tung's publications and public state$\&$ ments on the subject are more categorical, he says privately that g dioxin cannot be identified as the sole agent; the evidence for the link w with cancer is circumstantial and there 薄 is no good epidemiological evidence Jु to support it. He feels that there are many other possible factors to be $\approx$ considered, with aflatoxins and viruses obvious suspects. With a department specialising in the removal of liver tumours, however, Tung has seen an increasing number of patients referred to him for surgery, who do not come from any one particular area of the country. This makes it difficult to pinpoint any one agent.

In the opinion of many western scientists, the evidence implicating dioxin is very slim. They point out that there is a remarkably short time between the deposition of dioxinbeginning in 1962-and the appearance of liver tumours. Most known carcinogens have a latency period of between 20 and 30 years.

The final group of scientists involved in the assessment of herbicide damage are the zoologists at the Vietnam Scientific Research Centre in Hanoi. Dr Ngoc Quang, one member of this group, has some preliminary evidence of changes in the pattern of bird life in sprayed areas. "Normally", he says, "there is a population of about 40 peacocks per hectare. In areas sprayed with herbicides, there are none". He also reports a reduction in the pheasant population, and adds that scientists in Vietnam are "anxious to have help to assess the damage to our fauna. The changes we have recorded may not be due to the herbicides; there may be other causes."

Resolving the 'dioxin problem' is not one of Vietnam's top priorities; there are too many other areas, medical and agricultural, requiring urgent, immediate attention. What the long-term effects will be it is impossible to say; the evidence is just not available. With contamination on this scale, Vietnam is in a unique situation not to be envied. It is to be hoped that, when she asks for assistance from the scientific world, it will be promptly forthcoming.

Alastair Hay was recently in Vietnam as a Nature travelling fellow. He was supported in part by the London Technical Group. 